\title{
Behavior of spoilage bacteria and Salmonella enterica subspecies enterica 0:4,5 in vacuum-packaged beef during refrigeration
}

\author{
Jorge Luiz da Silva ${ }^{1,2,3}$ (D) Vasco Augusto Pilão Cadavez ${ }^{3}$ Maxsueli Aparecida Moura Machado ${ }^{2}$ \\ Brendo da Conceição Lima Dias ${ }^{2}$ Adelino da Cunha-Neto ${ }^{2}$ \\ Ursula Gonzales-Barron ${ }^{3}$ Eduardo Eustáquio de Souza Figueiredo ${ }^{2 *}$ iD
}

${ }^{1}$ Instituto Federal de Educação, Ciência e Tecnologia de Mato Grosso (IFMT), Cuiabá, MT, Brasil.

${ }^{2}$ Universidade Federal de Mato Grosso (UFMT), Cuiabá, MT, Brasil, 78060-900. E-mail: figueiredoeduardo@ufmt.br. *Corresponding author. ${ }^{3}$ Centro de Investigação de Montanha (CIMO), Escola Superior Agrária (ESA), Instituto Politécnico de Bragança (IPB), Bragança, Portugal.

\begin{abstract}
In this study, the kinetic parameters of mesophilic, psychrotrophic and lactic acid bacteria in vacuum-packed beef at $1{ }^{\circ} \mathrm{C}$ and 4 ${ }^{\circ} \mathrm{C}$ were estimated from experimental growth curves produced by samples stored during 21 and 60 days, respectively. In a separate experiment, the survival of multidrug resistant (MDR) Salmonella enterica $0: 4,5$ at $1^{\circ} \mathrm{C}$ was also characterized. The shelf-life of vacuum-packed beef stored at $4{ }^{\circ} \mathrm{C}$ was estimated at 16.1 days $\left(95 \% \mathrm{CI}: 14.8-17.3\right.$ days), whereas at $1{ }^{\circ} \mathrm{C}$ it was longer than 21 days because the mesophiles count estimated towards the end of the experiment was 12.5 ln CFU.g $g^{-1}\left(95 \%\right.$ CI: $11.8-13.3$ ln CFU.g ln $\left.^{-1}\right)$ which is lower than the shelf-life reference value. At $1^{\circ} \mathrm{C}$, inoculated Salmonella was reduced in 6.61 ln CFU.g $g^{-1}\left(2.87 \log C F U . g^{-1}\right)$. These results demonstrated the importance of establishing in legislation, especially in Brazil, standard values of deteriorating microorganisms in beef for maintaining product quality. Key words: deteriorating microorganisms, meat quality, predictive microbiology, Salmonella.
\end{abstract}

Comportamento de bactérias deteriorantes e Salmonella enterica subespécie entérica 0:4,5 em carne bovina embalada a vácuo durante refrigeração

RESUMO: Neste estudo, os parâmetros cinéticos de bactérias mesófilas, psicrotróficas e ácido lácticas foram estimados em carne bovina embalada a vácuo a $1{ }^{\circ} \mathrm{C}$ e $4^{\circ} \mathrm{C}$, a partir de curvas experimentais produzidas em amostras estocadas durante 21 e 60 dias, respectivamente. Em um experimento separado, a sobrevivência de Salmonella enterica $0: 4,5$ multirresistente (MDR) a $1^{\circ} \mathrm{C}$ também foi caracterizada. A vida de prateleira da carne bovina embalada a vácuo, estocada a $4^{\circ} \mathrm{C}$, foi estimada em 16.1 dias (95\% CI: 14.8 - 17.3 dias), enquanto que a $1{ }^{\circ} \mathrm{Co}$ periodo foi maior que 21 dias, porque a contagem estimada de mesófilos ao final do experimento foi de 12.5 ln UFC. $\mathrm{g}^{-1}$ (95\% CI: 11.8 - 13.3 ln $\left.U F C . g^{-1}\right)$, o qual é mais baixo que o valor referência de shelf-life. A $1^{\circ} \mathrm{C}$, Salmonella inoculada reduziu em 6.61 ln UFC.g ${ }^{-1}\left(2.87\right.$ log UFC.g $\left.{ }^{-1}\right)$. Estes resultados demonstram a importância de estabelecimento em legislação, especialmente no Brasil, de valores padrões para contagem de microrganismos deteriorantes em carnes visando manter a qualidade do produto.

Palavras-chave: microrganismos deteriorantes, qualidade de carne, microbiologia preditiva, Salmonella.

\section{INTRODUCTION}

The meat deterioration process is a combination of complex biological and chemical events caused by different bacterial populations. The most frequent microorganisms in fresh meat are Acinetobacter, Pseudomonas, Brochothrix, Flavobacterium, Psychrobacter, Moraxella, Staphylococcus, Micrococcus, lactic acid bacteria (LAB) and different Enterobacteriace genera (DOULGERAKI et al., 2012). These microorganisms are known as specific spoilage organisms (SSO) and understanding the development of this microbial community is paramount to ensure meat quality. Meat deterioration is characterized by discoloration, strong odor and slime production. It is mainly dependent of the storage temperature and packaging conditions (EFSA, 2014).

The shelf-life of a product is the time that it can be stored under appropriate conditions without changing its sensory characteristics in order to be fit for consumption. Maintenance of the cold storage chain is indispensable for controlling of SSO. The meat must be stored, transported and marketed at a temperature not exceeding $7{ }^{\circ} \mathrm{C}$ (BRAZIL, 1996). Despite the temperature limit recommendations, vacuum-packed beef shelf-life varies between different countries, estimated at 24 to 26 weeks at $-1{ }^{\circ} \mathrm{C}$ in Australia (MLA, 2016), 6 weeks at $0{ }^{\circ} \mathrm{C}$ in Europe (EFSA, 2014), 9 weeks at $-2.2^{\circ} \mathrm{C}$ in the USA (NATIONAL 
CATTLEMEN'S BEEF ASSOCIATION, 2009) and 18 weeks at $-1.5^{\circ} \mathrm{C}$ in Canada (GILL et al., 2013).

Salmonella is a foodborne pathogen frequently recovered from beef, as reported by the Food Safety and Inspection Service (FSIS, 2016). Thus, studies on Salmonella behavior under the recommended refrigeration temperatures are required. Predictive models describing microbiological growth or inactivation influenced by specific environmental conditions such as temperature, $\mathrm{pH}$ and water activity may predict process improvements and ensure food safety (GONZALES-BARRON et al., 2014).

Thus, considering the variability between refrigerated and vacuum-packed beef shelf-lives, defined by different legislations around the world, and the necessity to predict Salmonella behavior under such conditions, this study aimed to estimate the shelf-life of vacuum-packaged beef stored at temperatures between $1{ }^{\circ} \mathrm{C}$ and $4{ }^{\circ} \mathrm{C}$, and estimate the extent of Salmonella inactivation when it is vacuumpacked and stored at $1{ }^{\circ} \mathrm{C}$.

\section{MATERIALS AND METHODS}

Sirloin samples (Longissimus dorsi) were purchased from an abattoir located in the city of Cuiabá, Mato Grosso state, Brazil. This establishment works under the Federal Inspection Service (SIF) and complying with Good Manufacturing Practices (GMP) conditions. Total mesophilic microorganisms, psychrotrophic and lactic acid bacteria counts were quantified to characterize initial loads.

This research was divided into two experiments: the first (shelf-life study) evaluating mesophilic, psychrotrophic and lactic acid bacteria counts in vacuum-packed beef stored at $1{ }^{\circ} \mathrm{C} \pm 0.5$ ${ }^{\circ} \mathrm{C}$ and $4{ }^{\circ} \mathrm{C} \pm 0.5^{\circ} \mathrm{C}$; and the second study checking the behavior of Salmonella enterica O:4,5 multidrug resistant (MDR) inoculated in vacuum-packed beef stored at $1{ }^{\circ} \mathrm{C} \pm 0.5^{\circ} \mathrm{C}$. A total of 45 steaks ( 21 for analysis at $1{ }^{\circ} \mathrm{C}$ and 24 for evaluation at $4{ }^{\circ} \mathrm{C}$ ) weighing $100 \mathrm{~g}$ each were used in the first experiment. For the second experiment, a total of 15 steaks weighing $25 \mathrm{~g}$ each were analyzed. Three steaks per analysis day were analyzed in both experiments. All steaks were individually vacuum-packaged in low-density, gastight polyethylene bags $\left(150 \mathrm{~cm}^{3} / 24 \mathrm{~h} . \mathrm{m}^{2}\right.$.bar to $\mathrm{CO}_{2}$, $35 \mathrm{~cm}^{3} / 24 \mathrm{~h} . \mathrm{m}^{2}$.bar to $\mathrm{O}_{2}$ and $1.4 \mathrm{~cm}^{3} / 24 \mathrm{~h} . \mathrm{m}^{2}$.bar to $\mathrm{N}_{2}$ at $22{ }^{\circ} \mathrm{C}$ ) with the aid of BD-420 vacuum sealer (R-Baião, Ubá, Minas Gerais, Brazil).

The steaks were stored in a Biochemical Oxygen Demand (B.O.D.) incubator (model BT 71, Biotech, Piracicaba, São Paulo, Brazil) at $1{ }^{\circ} \mathrm{C} \pm 0.5^{\circ} \mathrm{C}$ for 21 days, and $4{ }^{\circ} \mathrm{C} \pm 0.5^{\circ} \mathrm{C}$ for 60 days. Total plate colony counts were performed on days $0,3,7,13,16$, 20, 21 and 0, 1, 4, 6, 10, 32, 46 and 60 for mesophilic aerobic bacteria, psychrotrophic bacteria and lactic acid bacteria according to the methods proposed by American Public Health Association (APHA, 2001). To this end, $10 \mathrm{~g}$ samples were separated and mixed with $90 \mathrm{~mL}$ of a peptone saline solution $(0.85 \% \mathrm{NaCl}$ and $0.1 \%$ peptone) and serial dilutions were prepared. For the mesophilic bacteria analyses, $0.1 \mathrm{~mL}$ of the appropriate dilutions were added by the spread plate technique in plate count agar (PCA) (Kasvi, São José dos Pinhais, Paraná, Brazil) and incubated at $36^{\circ} \mathrm{C} \pm$ $1{ }^{\circ} \mathrm{C}$ for 48 hours. The same inoculation and culture medium were used for psychrotrophic counts, with incubations carried out at $7^{\circ} \mathrm{C} \pm 1{ }^{\circ} \mathrm{C}$ for 10 days. For the lactic acid bacteria counts, $1.0 \mathrm{~mL}$ inoculum of appropriate dilutions was placed on the plate and MRS agar (Kasvi, São José dos Pinhais, Paraná, Brazil) was added by the pour plate technique with overlays, followed by incubation under anaerobiosis at $30^{\circ} \mathrm{C} \pm$ $1{ }^{\circ} \mathrm{C}$ for 48 hours. Three steaks were analyzed at each sampling point, in duplicate per dilution, and the $\mathrm{pH}$ value was determined in triplicate for every analysis day for each steak, using a digital $\mathrm{pH}$ meter (Kasvi, São José dos Pinhais, Paraná, Brazil) after adding 10-grams sample in $90 \mathrm{~mL}$ of distilled water.

In the second experiment, the meat samples were previously evaluated to determine the absence of Salmonella spp. (ISO, 2002). The Salmonella enterica subspecies enterica O:4,5, a MDR organism previously characterized by CUNHA-NETO et al. (2018), was used in this study. The isolated strain was stored at $-80{ }^{\circ} \mathrm{C}$. A loop full of isolated strain was added to $9 \mathrm{~mL}$ of TSB broth (Kasvi, São José dos Pinhais, Paraná, Brazil) and incubated at $36^{\circ} \mathrm{C} \pm$ $1^{\circ} \mathrm{C}$ for 24 hours. Serial dilutions (up to $10^{-10}$ ) were prepared in peptone saline solution, and $0.1 \mathrm{~mL}$ of each dilution, in duplicate, were added, spread on XLD agar plate (Kasvi, São José dos Pinhais, Paraná, Brazil). These plates were incubated at $36{ }^{\circ} \mathrm{C} \pm 1{ }^{\circ} \mathrm{C}$ for 24 hours. The characteristic colonies were counted, and the Salmonella concentrations in TSB broth were determined. Subsequently, the inoculum concentration was adjusted up to $6 \log$ CFU.g ${ }^{-1}$. Aliquots $(60 \mathrm{~mL})$ of this inoculum were prepared and $25 \mathrm{~g}$ steaks were immersed in this inoculum for 1 minute. After drying for $60 \mathrm{~s}$ in a laminar flux chamber, the steaks were individually vacuum-packed and stored in a B.O.D. incubator (model BT 71, Biotech, Piracicaba, São Paulo, Brazil) at $1{ }^{\circ} \mathrm{C} \pm 0.5^{\circ} \mathrm{C}$ for 21 days.

The analyses were conducted on the initial day and on days 3, 6, 12 and 21 of storage. 
Total plate count analyses for Salmonella colonies on XLD agar (Kasvi, São José dos Pinhais, Paraná, Brazil) were performed. On each day, three $25 \mathrm{~g}$ steaks were removed from the B.O.D. incubator, unpacked and individually stomached (model MA 440/CF, Marconi, Piracicaba, São Paulo, Brazil). One steak sample was homogenized for 1 minute in 225 $\mathrm{mL}$ of peptone saline solution $(0.85 \% \mathrm{NaCl}$ and $0.1 \%$ peptone). Serial dilutions (up to $10^{-4}$ ) were prepared, and $0.1 \mathrm{~mL}$ of the appropriate dilutions were spread onto XLD agar and incubated at $36{ }^{\circ} \mathrm{C} \pm 1{ }^{\circ} \mathrm{C}$ for 24 hours. Counting was performed with the aid of a colony counter (Prolab, São Paulo, Brazil), and the results were expressed in $\log$ CFU.g ${ }^{-1}$.

Both experiments were conducted in a completely randomized design with the data expressed as the means and standard error (SE). For the shelflife analysis, the $\log \mathrm{CFU} . \mathrm{g}^{-1}$ counts were converted to natural logarithm, and the reduced Huang model without lag phase (HUANG, 2008) was adjusted to each of the experimental growth curves of the spoilage indicators, using the statistical package $\mathrm{R}$ ( $\mathrm{R}$ DEVELOPMENT CORE TEAM, 2018). The kinetic parameters, initial microbial load ( $\mathrm{Y}_{0}$ in $\ln \mathrm{CFU} \cdot \mathrm{g}^{-1}$ ), maximum microbial load ( $\mathrm{Y}_{\max }$ in $\left.\ln \mathrm{CFU} \cdot \mathrm{g}^{-1}\right)$ and maximum growth rate $\left(\mu_{\max }\right.$ in $\mathrm{h}^{-1}$ ) were estimated for each of the three microbial groups at both $1{ }^{\circ} \mathrm{C}$ and $4{ }^{\circ} \mathrm{C}$.

In order to determine Salmonella kinetic parameters in vacuum-packed meat at $1{ }^{\circ} \mathrm{C}$, an empirical exponential decay model (Equation 1) without shoulder was fitted to the experimental survival curve (LEIKE, 2001), where $Y(t)$ represents the microbial counts at time $t, Y_{0}$ the initial microbial counts (ln CFU.g ${ }^{-1}$ ), $\mathrm{Y}_{\text {final }}$ the final asymptotic microbial concentration (ln CFU.g $\left.{ }^{-1}\right)$ and $\alpha$ the decay rate $\left(\right.$ day $\left.^{-1}\right)$.

$Y(t)=Y_{\text {final }}+\left(Y_{0}-Y_{\text {final }}\right) \times \exp (-a t)$

\section{RESULTS AND DISCUSSION}

Initial mesophile concentrations $\left(\mathrm{Y}_{0}\right)$ were

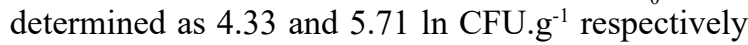
for $1{ }^{\circ} \mathrm{C}$ and $4{ }^{\circ} \mathrm{C}$, while initial lactic acid bacteria concentrations were lower, at $3.53 \ln \mathrm{CFU} . \mathrm{g}^{-1}$ at $1{ }^{\circ} \mathrm{C}$ and 3.17 ln CFU.g ${ }^{-1}$ at $4{ }^{\circ} \mathrm{C}$. Psychrotrophic bacteria displayed a low initial concentration at $1{ }^{\circ} \mathrm{C}$ of 3.73 $\ln$ CFU.g ${ }^{-1}$, and a higher concentration of $5.57 \ln$ CFU.g ${ }^{-1}$ at $4{ }^{\circ} \mathrm{C}$ (Table 1 ).

For mesophiles at $1{ }^{\circ} \mathrm{C}$, the end of the stationary phase was not evidenced after 21 days storage period by evaluating the adjusted growth curve (Figure 1A). This indicated that the maximum concentration is likely to be greater than $12.50 \mathrm{ln}$ CFU.g ${ }^{-1}$ determined at the end of the experiment, while at $4{ }^{\circ} \mathrm{C}$ the end of the stationary phase occurred close to 21 days of storage, at a concentration of 20.19 ln CFU.g ${ }^{-1}$ (Figure 1B).

Concerning the lactic acid bacteria growth curve at $1^{\circ} \mathrm{C}$ (Figure 1C), microbial concentration was determined with 3.53 ln CFU.g ${ }^{-1}$, without graphically displaying a relative exponential increase. At $4{ }^{\circ} \mathrm{C}$

Table 1 - Means and standard error of the kinetic parameters for mesophilic, lactic acid and psychrotrophic bacteria in vacuum-packed beef stored at $1{ }^{\circ} \mathrm{C}$ and $4{ }^{\circ} \mathrm{C}$ during 21 and 60 days respectively, and means, standard error and p-values of the parameter estimates for Salmonella enterica subspecies enterica $\mathrm{O}: 4,5$ in vacuum-packed meat stored at $1{ }^{\circ} \mathrm{C}$ for 21 days.

\begin{tabular}{|c|c|c|c|c|}
\hline Bacteria & Temperature & $\mathrm{Y}_{0} \pm \mathrm{SE}$ & $\mathrm{Y}_{\max } \pm \mathrm{SE}$ & $\mu_{\max } \pm \mathrm{SE}$ \\
\hline \multirow{2}{*}{ Mesophiles } & $1^{\circ} \mathrm{C}$ & $4.33 \pm 0.535$ & $12.50 \pm 1.581$ & $0.017 \pm 0.0020$ \\
\hline & $4^{\circ} \mathrm{C}$ & $5.71 \pm 0.165$ & $20.19 \pm 0.127$ & $0.027 \pm 0.0007$ \\
\hline \multirow{2}{*}{ Lactic Acid } & $1^{\circ} \mathrm{C}$ & $3.53 \pm 0.408$ & $6.08 \pm 0.496$ & $0.011 \pm 0.0055$ \\
\hline & $4{ }^{\circ} \mathrm{C}$ & $3.17 \pm 0.210$ & $10.93 \pm 0.133$ & $0.021 \pm 0.0014$ \\
\hline \multirow{2}{*}{ Psychrotrophic } & $1^{\circ} \mathrm{C}$ & $3.73 \pm 0.595$ & $14.70 \pm 1.086$ & $0.024 \pm 0.0025$ \\
\hline & $4{ }^{\circ} \mathrm{C}$ & $5.57 \pm 0.771$ & $18.93 \pm 0.420$ & $0.031 \pm 0.0044$ \\
\hline \multicolumn{5}{|c|}{ 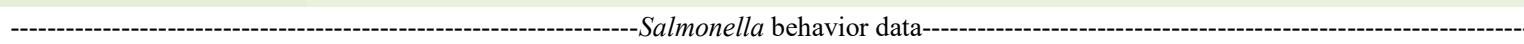 } \\
\hline Bacteria & Temperature & $\mathrm{Y}_{0} \pm \mathrm{SE}$ & $\mathrm{Y}_{\text {final }} \pm \mathrm{SE}$ & $\alpha \pm \mathrm{SE}$ \\
\hline Salmonella & $1^{\circ} \mathrm{C}$ & $13.94 \pm 0.600(\mathrm{P}<0001)$ & $7.32 \pm 0.482(\mathrm{P}<0001)$ & $0.300 \pm 0.083(\mathrm{P}=0.009)$ \\
\hline
\end{tabular}

$\mathrm{Y}_{0}=$ initial microbial concentration in $\ln \mathrm{CFU} \cdot \mathrm{g}^{-1} ; \mathrm{Y}_{\max }=$ maximum microbial concentration in $\ln$ CFU.g $\mathrm{g}^{-1} ; \mu_{\max }=$ maximum growth rate in $\ln$ CFU. $\mathrm{g}^{-1} \cdot \mathrm{h}^{-1} ; \mathrm{Y}_{\text {final }}=$ final microbial concentration in $\ln \mathrm{CFU} \cdot \mathrm{g}^{-1} ;$ decay rate $\left(\alpha\right.$ in $\left.\mathrm{d}^{-1}\right) ; \mathrm{SE}=$ standard error. 

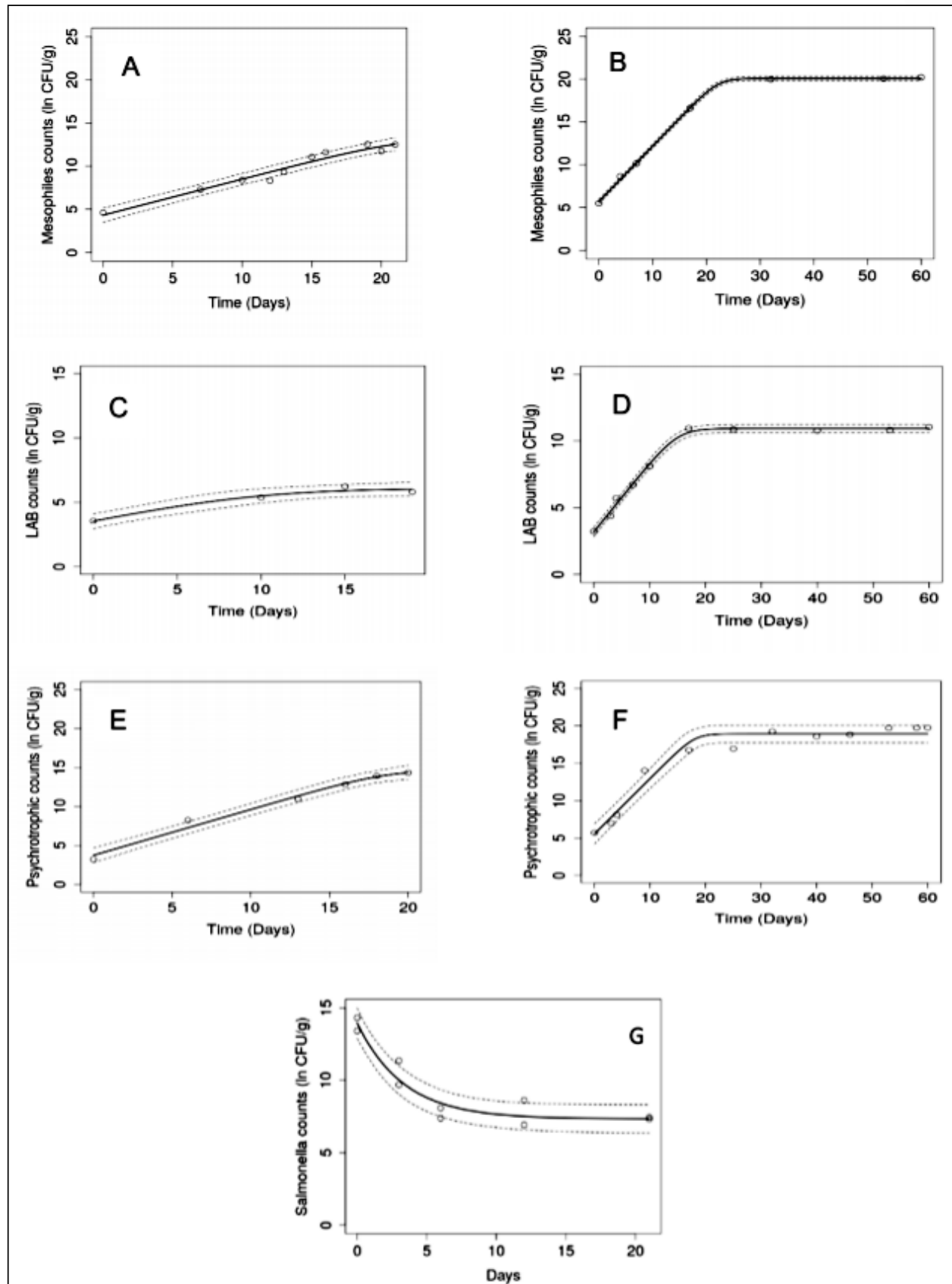

Figure 1 - Experimental and adjusted growth curves of mesophilic bacteria, lactic acid bacteria and psychrotrophic microorganisms in vacuum-packed beef refrigerated at $1{ }^{\circ} \mathrm{C}(\mathrm{A}, \mathrm{C}$ and $\mathrm{E})$ and $4{ }^{\circ} \mathrm{C}(\mathrm{B}, \mathrm{D}$ and $\mathrm{F})$ showing $95 \%$ confidence bands. Experimental and adjusted survival curve of Salmonella enterica subspecies enterica $\mathrm{O}: 4,5$ in vacuum-packed beef meat stored at $1{ }^{\circ} \mathrm{C}$, showing $95 \%$ confidence bands $(\mathrm{G})$.

(Figure 1D) the beginning of the stationary phase was observed shortly before approximately 19 days of storage, with a maximum concentration of $10.93 \mathrm{ln}$ CFU.g ${ }^{-1}$, and a 7.76 ln CFU.g Increase. $^{-1}$ in

In a study carried by REID et al. (2017), increased counts were observed from an initial concentration of $6.21 \mathrm{ln} \mathrm{CFU} / \mathrm{cm}^{2}$ to $13.57 \mathrm{ln} \mathrm{CFU} /$ $\mathrm{cm}^{2}$ for mesophilic counts, and $3.63 \mathrm{ln} \mathrm{CFU} / \mathrm{cm}^{2}$ to $11.34 \mathrm{ln} \mathrm{CFU} / \mathrm{cm}^{2}$ for $\mathrm{LAB}$ counts respectively in vacuum-packed meat stored at $2{ }^{\circ} \mathrm{C}$ for 6 weeks.

BARROS-VELÁZQUEZ et al. (2003) analyzed mesophiles and lactic acid bacteria 
concentrations in vacuum-packed meat stored at 4 ${ }^{\circ} \mathrm{C}$ for 70 days. They determined an initial amount of 10.88 ln CFU.g ${ }^{-1}$ for mesophiles and 9.29 ln CFU.g ${ }^{-1}$ for lactic acid bacteria. At 20 days of storage, the concentrations of both microorganism groups were greater than $18.4 \ln \mathrm{CFU}_{\text {. }}{ }^{-1}$, while at the end of 40 days, the concentrations of mesophiles and LAB were 25.3 and 21.96 ln CFU.g ${ }^{-1}$, respectively.

Concerning the psychrotrophic bacteria adjusted growth curves, the end of the exponential phase was reached approximately between 17 and 21 days of storage at $1{ }^{\circ} \mathrm{C}$ (Figure 1E), stabilizing at a maximum concentration of $14.7 \mathrm{ln} \mathrm{CFU} . \mathrm{g}^{-1}$, but for $4{ }^{\circ} \mathrm{C}$ (Figure 1F) psychrotrophic bacteria were in exponential phase at the end of 21 days, reaching 18.93 ln CFU. $\mathrm{g}^{-1}$. It is important to note that all the microorganisms reached the stationary phase at $4{ }^{\circ} \mathrm{C}$.

As expected, mesophiles, lactic acid bacteria and psychrotrophic bacteria displayed more accelerated growth rates in meat stored at $4{ }^{\circ} \mathrm{C}(0.027,0.021$ and $0.031 \mathrm{ln}$ CFU. $\left.\mathrm{g}^{-1} \cdot \mathrm{h}^{-1}\right)$ compared to meat stored at $1{ }^{\circ} \mathrm{C}$ $\left(0.017,0.011\right.$ and $\left.0.024 \ln \mathrm{CFU} \cdot \mathrm{g}^{-1} \cdot \mathrm{h}^{-1}\right)$. Psychrotrophic bacteria displayed higher growth rates compared to other microorganisms at each temperature, demonstrating this adaptability to cooling temperatures.

No standards for mesophilic, psychrotrophic and lactic acid bacteria are established in Brazilian legislation (BRAZIL, 2001). However, the current revision of the law recommends as unacceptable aerobic mesophiles concentrations above of $6 \mathrm{log}$ CFU.g ${ }^{-1}$ (13.82 ln CFU.g ${ }^{-1}$ ) in beef (BRAZIL, 2019). The European Community Commission recommends a maximum limit of $15.38 \mathrm{ln} \mathrm{CFU}^{-1} \mathrm{~g}^{-1}$ in cattle meat, while Chinese legislation considers values over $13.8 \mathrm{ln}$ CFU.g ${ }^{-1}$ as unsatisfactory (REGULATION E.C., 2005; CENTRE FOR FOOD SAFETY, 2014). These recommendations are lower than the result observed for this microorganism at $4{ }^{\circ} \mathrm{C}$ (Table 1).

The International Commission on Microbiological Specifications for Foods (ICMSF) advocates a count of $10^{7} \mathrm{CFU}_{\mathrm{g}} \mathrm{g}^{-1}\left(16.1 \mathrm{ln}_{\mathrm{CFU} . \mathrm{g}^{-1}}\right)$ of mesophiles as reference value in beef. The large number of microorganisms results in decreased meat glucose content, and the energy metabolism of deteriorating microorganisms degrades amino acids, producing metabolites such as ammonia, amines, sulfur compounds, aldehydes and ketones, which generate unpleasant odor, color and taste (ICMSF, 1986).

Based on the reference value of $16.1 \mathrm{ln}$ CFU.g ${ }^{-1}$ of mesophiles counts for end of shelf-life (ICMSF, 1986), in the present study we can state that, at $1{ }^{\circ} \mathrm{C}$, the shelf-life of vacuum-packed beef is longer than 21 days since the maximum value of mesophiles at the end of the experiment was $12.5 \ln$ CFU.g ${ }^{-1}$ (95\% CI: 13.3 - 11.8 ln CFU.g ${ }^{-1}$ ) (Table 1, and Figure $1 \mathrm{~A}$ ). For storage at $4{ }^{\circ} \mathrm{C}$, the shelf-life of vacuum-packed beef was 16.1 days $(95 \% \mathrm{CI}: 14.8-$ 17.3 days) (Figure 1B), where the concentration of mesophiles was exceeded the value recommended by the ICMSF (1986), as mesophile growth rates at $4{ }^{\circ} \mathrm{C}$ were higher than at $1^{\circ} \mathrm{C}$.

Beef producing industries must pay attention to the shelf-life studies of the product, as a transition from $1^{\circ} \mathrm{C}$ to $4^{\circ} \mathrm{C}$ is sufficient to promote considerable increases in the growth rate of these spoilage microorganisms, and it is paramount to maintain the lowest possible temperatures in all processes.

Regarding $\mathrm{pH}$ values in the vacuum-packed meat, no significant change between the initial and final concentrations $(\mathrm{P}>0.05)$ were observed for the meat samples stored at $1{ }^{\circ} \mathrm{C}(5.497 \pm 0.135$ to 5.463 $\pm 0.069)$ or $4{ }^{\circ} \mathrm{C}(5.696 \pm 0.153$ to $5.840 \pm 0.129)$; although, the meat samples stored at $4{ }^{\circ} \mathrm{C}$ presented greater $\mathrm{pH}$ variations.

In the study of Salmonella behavior in vacuum-packed beef during refrigeration, the initial Salmonella concentration was of $13.94 \mathrm{ln}$ CFU.g ${ }^{-1}$, and it declines in function of the time as can be graphically observed from the beginning of the experiment (Figure $1 \mathrm{G}$ ).

At the end of 21 days of storage, the final Salmonella concentration was of 7.324 ln CFU.g ${ }^{-1}$ (Table 1), demonstrating the action of low temperature and vacuum package in reducing the pathogen's population viability. In addition, this decline may also have occurred due to the accumulation of toxic metabolites by SSO growth during this period (Table 1, Figures $1 \mathrm{~A}, 1 \mathrm{C}$ and $1 \mathrm{E}$ ).

During the 21 days, a decline $(\mathrm{P}<.0001)$ in Salmonella concentrations from 6.616 ln CFU.g ${ }^{-1}$, almost half of the initial concentration with decline rate of the $0.3 \ln \mathrm{CFU} . \mathrm{g}^{-1} /$ day, occurred. However, it should be noted that from the initial concentration used, the microorganisms were not inactivated during 21 days under cooling.

Decreased Salmonella growth has been previously reported in vacuum-packed minced meat (DJORDJEVIĆ et al., 2018). Conversely, a study using a much lower storage temperature did not detect significant differences in the amounts of $S$. Typhimurium and $S$. Brandenberg inoculated in vacuum-packed meat stored at $-1.5^{\circ} \mathrm{C}$ for 8 weeks (DYKES, 2001). 
The decay rate of Salmonella enterica $0: 4,5$ in vacuum-packed beef meat estimated in this study $\left(0.300 \pm 0.083 \ln\right.$ CFU. $g^{-1} \cdot \mathrm{d}^{-1}$; Table 1$)$ is comparable to the inactivation rates $(0.365-0.578$ $\ln$ CFU. $\left.\mathrm{g}^{-1} \cdot \mathrm{d}^{-1}\right)$ estimated in another study that assessed the evolution of Salmonella Typhimurium in vacuum-packed pork meat, also stored at $1{ }^{\circ} \mathrm{C}$ (VAN LAACK et al., 1993). The extent of comparability is noteworthy, considering the differences in food matrix (beef versus pork), microbial quantification method (CFU versus most-probable-number) and Salmonella strain.

Maintaining Salmonella populations at low temperatures (cooling and/or freezing) during food storage represents a significant physiological challenge for the microorganism, promoting bacterial stress and metabolism alterations, such as cell membrane structure, DNA and transcriptional and translational response modifications. These changes render essential molecular processes, such as protein biosynthesis, ineffective; therefore, influencing bacterial growth rates (RICKE et al., 2018). Understanding Salmonella behavior in low temperatures can aid public health authorities, as well as all those involved in cattle meat marketing, on adequately storing meat and meat derivatives.

\section{CONCLUSION}

A shelf-life of over 21 days was estimated for vacuum-packed meat stored at $1{ }^{\circ} \mathrm{C}$, while the shelf-life of meat stored at $4{ }^{\circ} \mathrm{C}$ was 16.1 days. This could support regulation and decision-making within the meat industry, preventing the marketing of low nutritional value meat. Concerning the Salmonella enterica enterica serovar O:4,5, a growth rate decline was noted at $1{ }^{\circ} \mathrm{C}$, demonstrating that lower conservation temperatures in conjunction with vacuum packaging is an effective strategy to reduce consumer exposure to Salmonella through the consumption of beef meat.

\section{ACKNOWLEDGEMENTS}

The authors thank the Coordenação de Aperfeiçoamento de Pessoal de Nível Superior (CAPES), Brazil, for supporting the first author with a scholarship from the International Sandwich Exchange Program (PDSE) approved at the Call 047/2017/Process: 88881.189927/201801 . We also thank the Conselho Nacional de Desenvolvimento Científico e Tecnológico (CNPq), Brazil (Process: 310462 / 2018-5), and the Instituto Federal de Educação, Ciência e Tecnologia de Mato Grosso (IFMT) for their support. Our gratitude also to the "Ad hoc" evaluators who reviewed our work and contributed to its improvement.

\section{DECLARATION OF CONFLICT OF INTERESTS}

The authors declare no conflict of interest. The founding sponsors had no role in the design of the study; in the collection, analyzes, or interpretation of data; in the writing of the manuscript, and in the decision to publish the results.

\section{AUTHORS' CONTRIBUTIONS}

EESF and JLS conceived and designed experiments. JLS, EESF, ACN and MAMM performed the experiments. JLS, MAMM, ACN and BCLD carried out the lab analyses. VAPC, UGB, EESF and JLS performed statistical analyses of experimental data. JLS, EESF, UGB and VAPC prepared the draft of the manuscript. All authors critically revised the manuscript and approved the final version.

\section{REFERENCES}

APHA - American Public Health Association. Compendium of methods for the microbiological examination of foods. $4^{\text {th }}$ ed. 2001. Washington, D.C.

BARROS-VELÁZQUEZ, J. et al. Microbiological and physicochemical properties of fresh retail cuts of beef packaged under an advanced vacuum skin system and stored at $4{ }^{\circ} \mathrm{C}$. Journal of Food Protection, v.66, p.2085-2092, 2003. Available from: $<$ https://doi.org/10.4315/0362-028x-66.11.2085>. Accessed: Nov. 02, 2019. doi: 10.4315/0362-028x-66.11.2085.

BRAZIL. National Health Surveillance Agency (ANVISA). IN n. ${ }^{\circ}$ 60 of December 23, 2019.

BRAZIL. National Health Surveillance Agency (ANVISA). RDC Resolution n. ${ }^{\circ} \mathbf{1 2}$ of January 02,2001

BRAZIL. Ministry of Agriculture, Livestock and Supply. Ordinance $n^{\circ} 304$ of April 22, 1996.

CENTRE FOR FOOD SAFETY. Food and Environmental Hygiene Department. Microbiological Guidelines for ready-to-eat Food. 2014. Available from: $<$ https://www.cfs.gov.hk $>$. Accessed: Jun. $02,2019$.

CUNHA-NETO, A. et al. Salmonella isolated from chicken carcasses from a slaughterhouse in the state of Mato Grosso, Brazil: antibiotic resistance profile, serotyping and characterization by repetitive sequence-based PCR system. Poultry Science, v.97, p.1373 - 1381, 2018. Available from: <https://dx.doi.org/10.3382/ ps/pex406>. Accessed: Dec. 02, 2018. doi: 10.3382/ps/pex406.

DJORDJEVIĆ, J. et al. Survival of Salmonella spp. in minced meat packaged under vacuum and modified atmosphere. Brazilian Journal of Microbiology, v.49, p.607-613, 2018. Available from: $<$ https://doi.org/10.1016/j.bjm.2017.09.009>. Accessed: Jan. 02, 2019. doi: 10.1016/j.bjm.2017.09.009.

DOULGERAKI, A.I. et al. Spoilage microbiota associated to the storage of raw meat in different conditions. International Journal of Food Microbiology, v.157, p.130-141, 2012. Available from: $<$ https://doi.org/10.1016/j.ijfoodmicro.2012.05.020>. Accessed: Jan. 02, 2019. doi:10.1016/j.ijfoodmicro.2012.05.020. 
DYKES, G.A. et al. Survival of Escherichia coli O157:H7 and Salmonella on chill-stored vacuum or carbon dioxide packaged primal beef cuts. International Journal of Food microbiology, v.64, p.401-405, 2001. Available from: <https://doi.org/10.1016/ s0168-1605(00)00482-7>. Accessed: Feb. 02, 2019. doi: 10.1016/ s0168-1605(00)00482.

EFSA - European Food Safety Authority. Scientific opinion on the public health risks related to the maintenance of the cold chain during storage and transport of meat. Part 1 (meat of domestic ungulates), v.12, 81p., 2014. Available from: <https:// doi.org/10.2903/j.efsa.2014.3601>. Accessed: Oct. 02, 2019. doi: $10.2903 /$ j.efsa.2014.3601.

FSIS - Food Safety and Inspection Service. Serotypes profile of Salmonella isolates from meat and poultry products January 1998 through December 2014. 2016. Available from: <https:// www.fsis.usda.gov>. Accessed: May, 02, 2019.

GILL, C.O. et al. Storage life of vacuum packaged beef. Beef Cattle Research Council. BCRC. 2013. Available from: <www. beefresearch.ca/factsheet.cfm/storage-life-of-vaccum-packagedbeef-65>. Accessed: May, 02, 2019.

GONZALES-BARRON, U. et al. An exposure assessment model of the prevalence of Salmonella spp. along the processing stages of Brazilian beef. Food Science and Technology International, v.22, p.10-20, 2014. Available from: $<$ https://doi. org/10.1177/1082013214560446>. Accessed: Apr. 02, 2019. doi: $10.1177 / 1082013214560446$

HUANG, L. Growth kinetics of Listeria monocytogenes in broth and beef Frankfurters -determination of lag phase duration and exponential growth rate under isothermal conditions. Journal of Food Science, v.73, p.235-242, 2008. Available from: <https:// doi.org/10.1111/j.1750-3841.2008.00785.x>. Accessed: May, 02, 2019. doi: 10._1111/j.1750-3841.2008.00785.x.

ICMSF - International Commission on the Microbiological Specification of Foods. Microorganisms in Food 2. Sampling for microbiological analysis: principles and specific application. Second edition, 1986. University of Toronto press.
ISO - International Organization for Standardization. Microbiology of food and animal feeds stuffs - Horizontal Methods for the detection of Salmonella spp. 2002.

LEIKE, A. Demonstration of the exponential decay law using beer froth. European Journal of Physics, v.23, p.21-26, 2001 Available from: < https://doi.org/10.1088/0143-0807/23/1/304>. Accessed: May, 02, 2019. doi: 10.1088/0143-0807/23/1/304.

MLA - Meat and Livestock Australia. Shelf-life of Australian red meat. Second edition. 182p., 2016. Tasmanian Institute of Agriculture, Australia. ISBN 9781740362399

NATIONAL CATTLEMEN'S BEEF ASSOCIATION. Cattlemen's Beef Board and National Cattlemen's Beef Association. Beef shelflife. 2009. Research RKM \& Knowledge management. Available from: $<$ https://www.beefresearch.org $>$. Accessed: Apr. 02, 2019.

R DEVELOPMENT CORE TEAM. R: a language and environment for statistical computing. $R$ Foundation for Statistical Computing, Vienna, Austria, 2018. Available from: $<$ https://www.r-project.org > . Accessed: Nov. 02, 2018.

REGULATION E.C. N. ${ }^{\circ} 2073 / 2005$ of the European Parliament and of the Council of 15 November 2005 on microbiological criteria for foodstuffs. Official Journal of the European Union.

RICKE, S.C. et al. Chapter one - Salmonella cold stress response: mechanisms and occurrence in foods. Advances in Applied Microbiology, v.104, p.1-38, 2018. Available from: $<$ https://doi. org/10.1016/bs.aambs.2018.03.001>. Accessed: Dec. 02, 2018 doi: 10.1016/bs.aambs.2018.03.001

RIED, R. et al. Comparison of hot versus cold boning of beef carcasses on bacterial growth and the risk of blown pack spoilage. Meat Science, v.125, p.46-52, 2017. Available from: <http:/ dx.doi.org/10.1016/j.meatsci.2016.11.012>. Accessed: Oct. 02, 2018. doi: 10.1016/j.meatsci.2016.11.012.

VAN LAACK, R.L.J.M. et al. Survival of pathogenic bacteria on pork loins as influenced by hot processing and packaging. Journal of Food Protection, v.56, p.847-851., 1993. Available from: $\quad<$ https://jfoodprotection.org/doi/pdf/10.4315/0362028x-56.10.847>. Accessed: Feb. 02, 2019. 